\title{
Native forbs produce high quality seeds on Chicago green roofs
}

\author{
Kelly Ksiazek ${ }^{1}$, Jeremie Fant ${ }^{2}$, Krissa Skogen $^{3}$ \\ ${ }^{1} \mathrm{PhD}$ Candidate, Northwestern University, Evanston, IL, kellyksiazek2011@u.northwestern.edu \\ ${ }^{2}$ Ecologist, Chicago Botanic Garden, Glencoe, IL, jfant@ chicagobotanic.org \\ ${ }^{3}$ Ecologist, Chicago Botanic Garden, Glencoe, IL, kskogen@ chicagobotanic.org
}

Ksiazek, K., Fant, J., Skogen, K., 2014. Native forbs produce high quality seeds on Chicago green roofs. Journal of Living Architecture. 1(2): 21-33. http://greenroofs.org/resources/JOLA2014Volume1(Issue2)Ksiazek(etal) 


\begin{abstract}
Although a paucity of bees on Chicago green roofs suggests some plants may experience reduced pollination and thus poor seed production, a previous investigation revealed high seed set in green roof plants. However, high quantity of seeds does not always imply high quality. In this study, we compared seed germination between green roof and ground-level locations. We hypothesized that forb seeds from green roofs would have lower germination due to differences in maternal provisioning and environmental stressors. We found that green roof seeds did not have lower germination; this supports the continued use of native forbs on green roofs.
\end{abstract}

Keywords: green roofs, native plants, plant reproduction, seed germination

\title{
Introduction
}

Many human-dominated landscapes are being redesigned under the guiding principle of reconciliation ecology (Rosenzweig 2003), which fosters cooperative living between people and native organisms to promote a greater diversity of species. Green roofs are good examples of this design (Francis and Lorimer 2011) as they provide the opportunity for a single piece of land to be used for both residential and commercial purposes as well as habitat for plants and animals. It is well known that green roofs provide many environmental benefits compared to non-vegetated roofs, including reduced energy needed for building insulation and cooling, stormwater runoff capture, urban heat-island effect mitigation and air pollution abatement (Carter and Butler 2008, Dunnett et al. 2008, Getter and Rowe 2006, Oberndorfer et al. 2007, Rowe 2011, Snodgrass and Snodgrass 2006, Spala et al. 2008, Susca et al. 2011).

Green roofs could also play a role in supporting biodiversity in urban environments (Oberndorfer et al. 2007). There are many benefits that diverse plantings on green roofs can provide, specifically when local native species are the main plantings or when they supplement traditional plantings of Sedum and other succulent species. For example, green roofs planted to mimic local natural habitats can attract many species of birds (Bumann 2006, Brenneisen 2006, FernandezCanero and Gonzalez-Redondo 2010) and insects (Colla and Willis 2009, Kadas 2006, Ksiazek et al. 2012, MacIvor and Lundholm 2011, Tonietto et al. 2011) which may use the roofs for nesting, mating, or foraging sites and may serve as components of larger migration corridors. Plantings of native species such as grasses and forbs are more effective at retaining stormwater than succulent species (Dunnett et al. 2008, MacIvor and Lundholm 2011) and contribute positively to overall ecosystem function (Lundholm and MacIvor 2010).

Previous studies found that pollinator communities on green roofs can differ from those on the ground (Colla and Willis 2009, MacIvor and Lundholm 2011, Tonietto et al. 2011). If certain 
pollinators are lacking, native plants that require locally-adapted insect pollination may not produce enough high-quality seeds to sustain populations on green roofs over time. In a previous study, we found that although green roofs support fewer and less diverse pollinator communities, native plants on green roofs do not suffer from a lack of quality pollen (Ksiazek et al. 2012). That study showed native forbs required pollinators to produce the maximum seed set but the number of seeds was not significantly lower than for forb species on green roofs compared to reference habitats on the ground. Rather, when data from all selected forb species were combined, seed set was higher on green roofs than on the ground. While these results were contrary to our expectations, more accurate measures of reproductive success such as ability of seeds to germinate (viability), actual germination percentage and seedling survivorship, may reveal differences that seed set alone does not.

The current investigation builds on our previous quantitative study and examines differences in seed quality induced by resource limitation or environmental stress experienced on green roofs by plants during seed maturation (Westoby et al. 1996). Ground-level habitats have deeper soil profiles than green roofs and, thus, plants with considerably larger root systems (Craine et al. 2003, Sun et al. 1997) would be expected to have access to higher proportions of available below-ground organic matter compared to shallow extensive green roofs. Plants in resourcelimited environments can still produce many seeds, but a common trade-off associated with higher seed production is smaller seed and lower viability (deJong and Klinkhamer 2005). We tested the hypothesis that seeds produced on green roofs would be smaller and less likely to germinate than those from ground-level sites.

\section{Methods}

\section{SPECIES AND SITE SELECTION}

Ten native Illinois species were selected for analysis in the germination study (Table 1). Species were chosen that bloomed at various times during the typical foraging season of local pollinators (April through September, Table 1) so that a wide variety of pollinators might be attracted to the pollen or nectar of the individual plants. Species were also chosen based on their status as native to Illinois as well as their prevalence in other natural areas in North America (Table 1). All species rely on biotic pollinators such as bees and butterflies (see Davis and Hendrix 2008 and Hilty 2012 for known pollinators) for maximum seed production, though none were known to be $100 \%$ obligate outcrossers.

Table 1. Species and seed collection information. Prevalence in North America is listed as the number of U.S. states (including the District of Columbia) and Canadian provinces/territories in which the species is found in ground-level habitats. 


\begin{tabular}{lccccc}
\multicolumn{1}{c}{ Species } & Bloom period & $\begin{array}{c}\text { Number of } \\
\text { Individuals } \\
\text { (ground/roof) }\end{array}$ & $\begin{array}{c}\text { Number of } \\
\text { Sites } \\
\text { (ground/roof) }\end{array}$ & $\begin{array}{c}\text { Scarification } \\
\text { Treatment } \\
\text { Applied }\end{array}$ & $\begin{array}{c}\text { Prevalence } \\
\text { (states/provinces) }\end{array}$ \\
\hline Allium cernuum (nodding onion) & early - mid August & $70 / 67$ & $3 / 3$ & no & $34 / 4$ \\
Amorpha canescens (lead plant) & late June - late July & $23 / 50$ & $1 / 2$ & yes & $19 / 2$ \\
Aquilegia canadensis (red columbine) & late May - mid June & $58 / 48$ & $3 / 3$ & no & $37 / 5$ \\
Asclepias tuberosa (butterfly weed) & mid June - late July & $15 / 8$ & $3 / 1$ & no & $42 / 2$ \\
Baptisia alba (wild white indigo) & early - mid June & $34 / 3$ & $4 / 1$ & yes & $24 / 0$ \\
Baptisia australis (blue wild indigo) & late May - mid June & $33 / 9$ & $2 / 1$ & yes & $29 / 1$ \\
Dalea purpurea (purple prairie clover) & early - late July & $24 / 75$ & $1 / 3$ & yes & $27 / 4$ \\
Monarda fistulosa (wild bee balm) & mid July - mid August & $77 / 50$ & $3 / 2$ & no & $49 / 7$ \\
Penstemon digitalis (foxglove penstemon) & mid June - early July & $51 / 33$ & $4 / 2$ & no & $36 / 4$ \\
Zizia aurea (golden Alexander) & late May - mid June & $49 / 18$ & $3 / 3$ & no & $39 / 5$ \\
\hline
\end{tabular}

Three green roofs and four ground-level locations in greater Chicago were chosen for this research (Table 2). Each site had at least five of the ten selected species present (Table 1). Green roofs plants were originally started from nursery plugs while individuals at the ground level locations originated from both seeds and potted nursery plants. 
Table 2. Study site information.

\begin{tabular}{|c|c|c|c|c|c|c|}
\hline Site Name & Site Type & City & Latitude & Longitude & $\begin{array}{l}\text { Green Roof } \\
\text { Completion }\end{array}$ & $\begin{array}{c}\text { Green Roof } \\
\text { Height (stories) }\end{array}$ \\
\hline Chicago Botanic Garden & Roof and Ground & Glencoe & 42.14443 & -87.78591 & 2009 & 2 \\
\hline Chicago City Hall & Roof & Chicago & 41.88385 & -87.63240 & 2001 & 13 \\
\hline Center for Green Technology & Ground & Chicago & 41.88916 & -87.70072 & N/A & N/A \\
\hline Peggy Notebaert Museum & Roof and Ground & Chicago & 41.92662 & -87.63490 & 2002 & 3,4 \\
\hline Waters School & Ground & Chicago & 41.96338 & -87.69181 & N/A & N/A \\
\hline
\end{tabular}

\section{SEED COLLECTION AND GERMINATION}

The study was carried out in 2010, a growing season (March-August) slightly warmer and much wetter than what is typical for Chicago. The average high temperature was $23.2^{\circ} \mathrm{C}$ compared to an average of $21.5^{\circ} \mathrm{C}$ during the previous ten years and the average low was $13.8^{\circ} \mathrm{C}$ compared to the previous ten-year average of $12.1^{\circ} \mathrm{C}$. Total spring and summer precipitation in 2010 was $782.4 \mathrm{~mm}$ compared to the previous ten-year average of $465.9 \mathrm{~mm}$.

Seeds were collected from two pollination treatments conducted in our previous study (Ksiazek et al. 2012): untreated or supplemental pollination. Untreated individuals were tagged but otherwise undisturbed, while individuals in the supplemental pollen treatment received an additional mixture of pollen applied using a fine brush. After fruits developed, seeds were collected, counted, dried and weighed; seeds from individual plants were kept separate to prevent biased sampling from maternal lines with greater seed sets. Subsequent data analysis revealed no significant difference in seed set or seed weight between the untreated and supplemental pollination treatments (Ksiazek et al. 2012). Therefore, seeds from both treatments at each site were mixed and selected at random for the germination experiment.

Agar plates (95mm x 15mm) were prepared using a $0.75 \%$ solution of Agar (Bacteriology Grade Agar; Fisher BioReagents ${ }^{\circledR}$ 9002-18-0). Seeds were sterilized by dipping them briefly in a $10 \%$ bleach solution and were double rinsed in sterilized deionized water. Seeds requiring scarification (Table 3) were agitated for 30 seconds between two sheets of medium grain sandpaper to abrade the seed coat. Ten seeds per individual plant were randomly assigned one quarter of a prepared agar plate. For each site type, seeds from $3-77$ individuals (mean $39.7 \pm$ 5.02) per species were plated, according to the availability of seed. All plates were sealed with Parafilm® (Pechiney Plastic Packaging Company) to retain moisture and placed in dark, moist, cold stratification at $4^{\circ} \mathrm{C}$ for the time period suggested by the common literature for each species (Table 3). Plates were then moved to a single incubator (Intellus environmental controller, Model 136LLVL; Percival Scientific, Inc.) set to a common Chicago springtime temperature diurnal schedule of $23 / 13^{\circ} \mathrm{C}(12: 12 \mathrm{~h})$ with a relative humidity of $60 \%$. 
Germination, defined here as the emergence of the root radicle, was recorded every four days (or more frequently if a species germinated very quickly) until all seeds had germinated or until there was no change in overall percent germination over a one-week period. To eliminate over influence of outliers associated with late germination, time to $50 \%$ germination of seed was calculated for each species by site-type combination, using the asymptotic point at which half of the seeds had germinated. Time to 50\% germination was rounded up to the nearest whole day. Germination percent was also tested against measurements of seed set (number of seeds produced) and seed weight from our previous study (Ksiazek et al. 2012) to test for correlations by site type across all species

\section{DATA ANALYSES}

All data were analyzed using $\mathrm{R}$ version 2.10.1. (R Development Core Team 2009). Seed germination was first analyzed by pollination treatment using Student's $t$ test to determine whether the assigned pollination groups from the previous study affected viability. Binominal linear models were used to compare viability between site type for each species. Tests for correlations between seed set and percent viability, and between seed weight and percent viability were performed to determine the relationship between seed set, seed weight, and total germination on green roofs and ground-level sites. 


\section{Results}

Mean germination of seeds collected from the untreated $(73.2 \% \pm 2 \%)$ and supplemental pollination $(72.8 \% \pm 2 \%)$ treatments did not differ significantly ( $\mathrm{p}=0.876$ on $684 \mathrm{DF}$ ) and, as a consequence, data was pooled for the remaining analyses.

Figure 1. Mean germination of seeds from ten native Illinois prairie species at ground-level sites and green roofs \pm standard error. (* indicates a significant difference at the $\mathrm{p}<0.05$ level and $* *$ indicates significance at the $\mathrm{p}<0.001$ level.) Baptisia alba seeds from green roofs did not germinate.

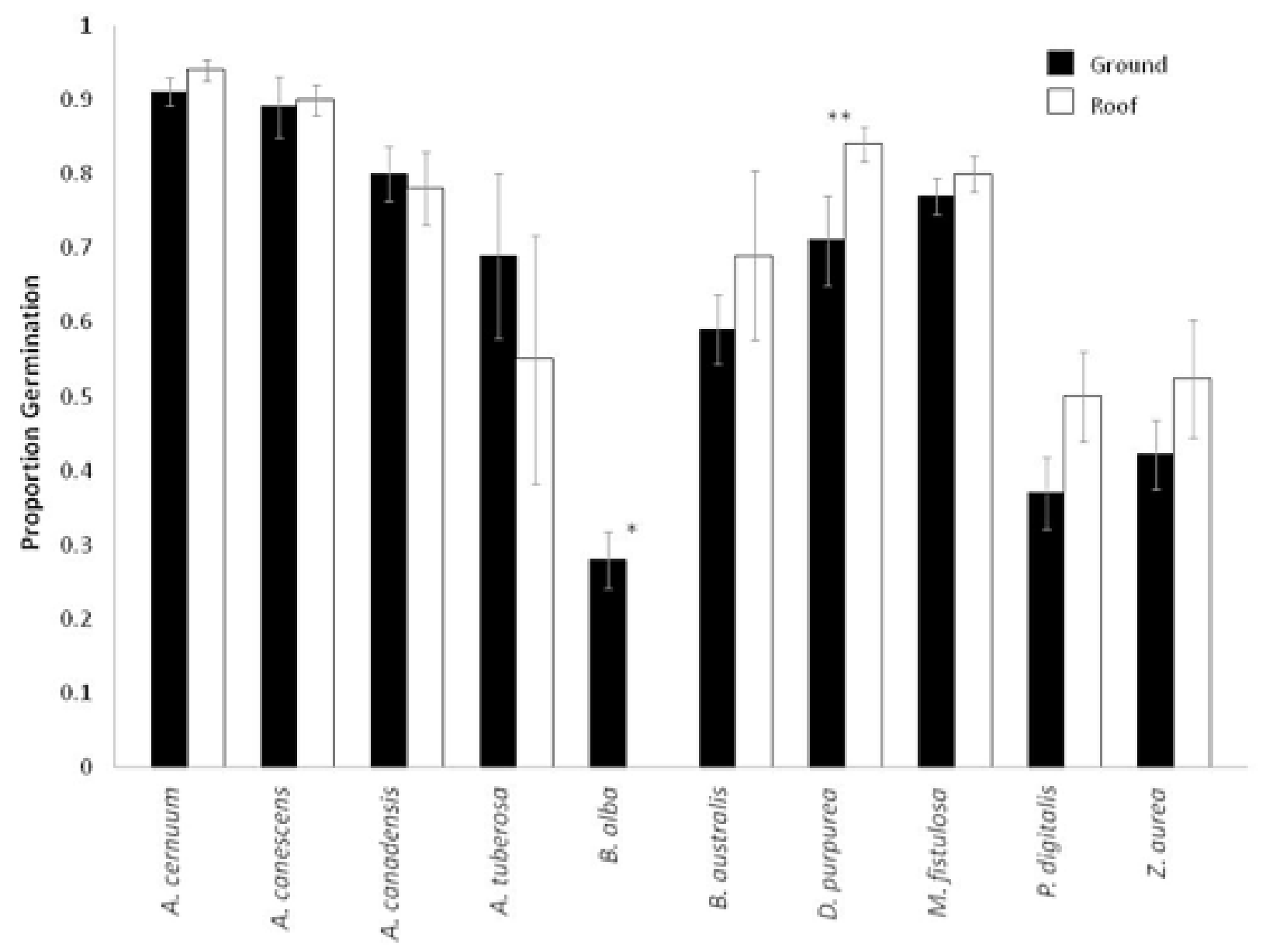

Seed germination varied by species such that species was a significant predictor of total germination proportion (ANOVA, $\mathrm{p}<0.001, \mathrm{~F}_{51,784}$ ). The majority of seeds from green roofs (in seven of ten species) appeared to germinate more quickly compared to seeds from the ground level. However, binomial linear models revealed that the observed higher germination was not significant in most cases (Figure 1). The two exceptions were Dalea purpurea, which had a 
significantly higher mean germination (ANOVA, $\left.\mathrm{p}<0.001, \mathrm{~F}_{8,97}\right)$ in green roof seeds $(0.832 \pm$ $0.02, N=75$ plants) than seeds collected from the ground-level reference populations $(0.682 \pm$ 0.06, $N=24$ plants) and Baptisia alba, which had significantly higher (ANOVA, p<0.05, $\mathrm{F}_{5}, 35$ ) mean germination on the ground $(0.295 \pm 0.04, N=34$ plants) compared to the roof (no germination, $N=3$ plants; Figure 1).

Figure 2. Proportion of seeds germinated by days since transfer from cold stratification for nine native Illinois prairie species at ground level sites (solid lines) and green roofs (dashed lines). Baptisia alba seeds from the green roofs had a total germination of $0 \%$ and therefore data are not included.
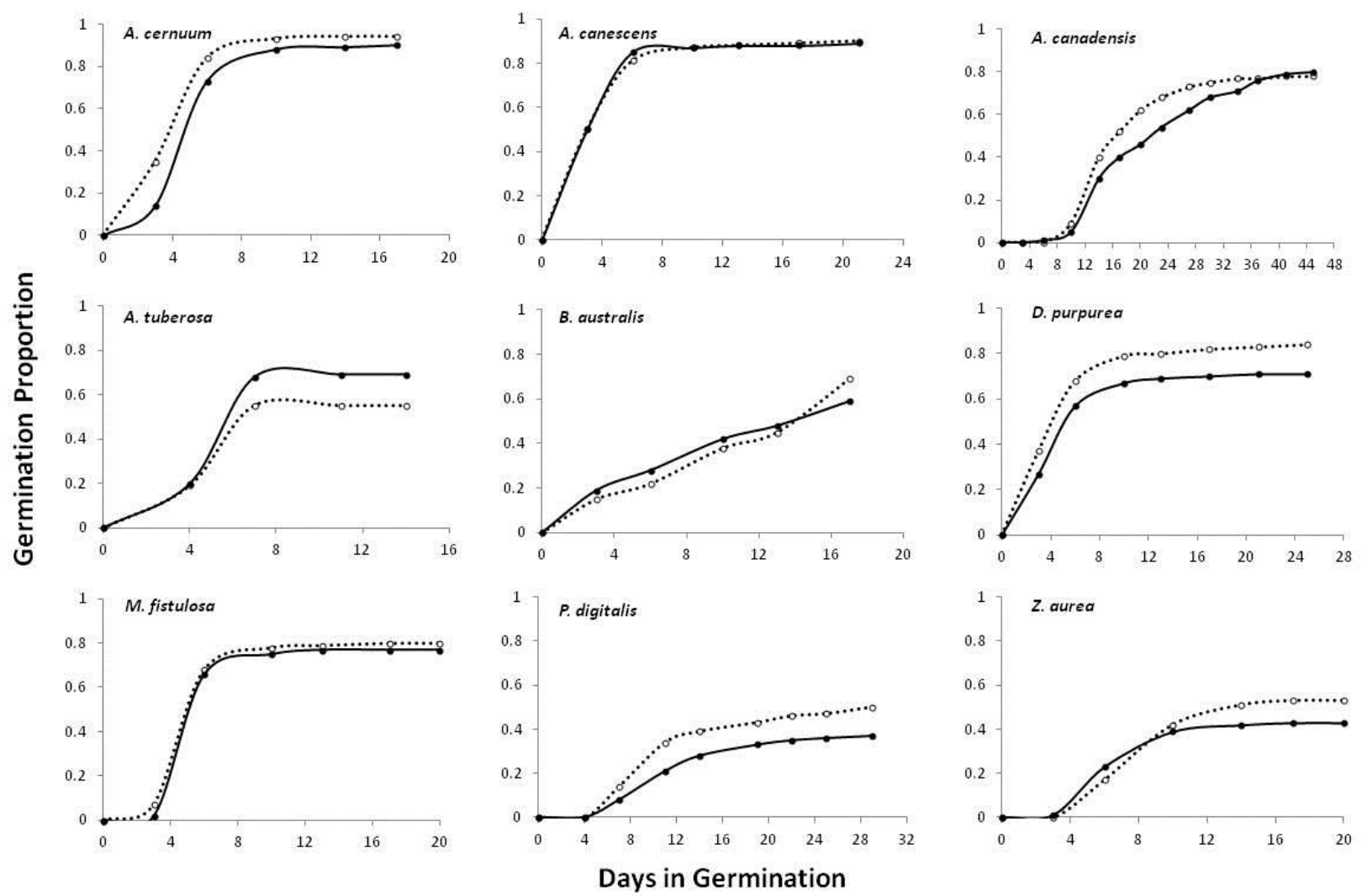

When data from all species were pooled, seeds from green roofs had an overall higher mean germination proportion $(0.786 \pm 0.01)$ than those from ground-level sites $(0.658 \pm 0.02 ; \mathrm{p}<0.001$ on $792 \mathrm{DF})$. Cumulative germination proportion over time plots revealed little difference in germination by site type within each species (Figure 2) while ratios comparing the total germination between the ground and the roof for each species also revealed differences for about half of the species (Table 3). For all species combined, it took an average of seven days to reach $50 \%$ germination and 19 days to reach $100 \%$ germination of viable seed (Table 3 ). These data were the same for both site types. Seeds from green roofs and ground-level sites had identical days to $50 \%$ and $100 \%$ germination for three of the ten species (A. canescens, A. tuberosa, and 
M. fistulosa; Table 3). The largest within-species germination discrepancies between site types were for B. australis and A. canadensis with a three-day difference to $50 \%$ germination, and $A$. cernuum and $P$. digitalis with a four-day difference to $100 \%$ germination (Table 3 ), excluding data from $B$. alba, as no seeds of that species from green roofs germinated. There were statistically significant positive relationships between seed set and percent germination $(p<0.001)$ as well as seed weight and percent germination $(\mathrm{p}<0.001)$.

Table 3. Length of stratification period, comparison of total germination percentages and total germination periods for all viable seed from native forb populations on the ground and green roofs. Baptisia alba seeds from the green roofs did not germinate.

\begin{tabular}{lcccccc} 
& & & \multicolumn{2}{c}{ Ground } & \multicolumn{2}{c}{ Roof } \\
\multicolumn{1}{c}{ Species } & $\begin{array}{c}\text { Days in cold } \\
\text { stratification }\end{array}$ & $\begin{array}{c}\text { Germination ratio } \\
\text { (ground to roof) }\end{array}$ & $\begin{array}{c}\text { Days to } \\
\mathbf{5 0 \%}\end{array}$ & $\begin{array}{c}\text { Days to } \\
\mathbf{1 0 0 \%}\end{array}$ & $\begin{array}{c}\text { Days to } \\
\mathbf{5 0 \%}\end{array}$ & $\begin{array}{c}\text { Days to } \\
\mathbf{1 0 0 \%}\end{array}$ \\
\hline A. cernuum & 56 & $1.00: 1.03$ & 5 & 14 & 4 & 10 \\
A. canescens & 16 & $1.00: 1.01$ & 3 & 21 & 3 & 21 \\
A. canadensis & 52 & $1.00: 1.00$ & 17 & 37 & 14 & 37 \\
A. tuberosa & 31 & $1.25: 1.00$ & 5 & 7 & 5 & 7 \\
B. alba & 15 & $1.00: 0.00$ & 7 & 25 & N/A & N/A \\
B. australis & 15 & $1.00: 1.17$ & 7 & 17 & 10 & 17 \\
D. purpurea & 0 & $1.00: 1.83$ & 4 & 17 & 4 & 21 \\
M. fistulosa & 31 & $1.00: 1.04$ & 5 & 13 & 5 & 13 \\
P. digitalis & 0 & $1.00: 1.35$ & 11 & 25 & 10 & 29 \\
Z. aurea & 57 & $1.00: 1.24$ & 6 & 14 & 8 & 17 \\
\hline \multicolumn{1}{c}{ Mean } & & $\mathbf{1 . 0 0 : 1 . 0 4}$ & $\mathbf{7}$ & $\mathbf{1 9}$ & $\mathbf{7}$ & $\mathbf{1 9}$ \\
\hline
\end{tabular}

\section{Discussion}

For any short lived native forbs to be economically-practical candidates for green roof plantings they need to be capable of reproducing and successfully sustaining their populations under rooftop growing conditions. Production of seeds is a necessary first step for long-term population persistence but seeds must also be of sufficient quality to germinate, grow, and survive to reproductive maturity. This investigation supports recent findings (Ksiazek et al. 2012) that native forbs on green roofs have similar or better reproductive abililties than those growing at ground-level. In contrast to our original hypothesis, these species growing on green roofs produced many high-quality seeds which were able to germinate at similar frequencies as the same species growing on the ground. Time to germination for plants on green roofs and ground 
level sites were very similar although overall the seeds from green roofs had a higher mean percent germination, compared to the seeds from ground-level sites.

Only one species, $B$. alba, had individuals with significantly lower germination success in green roof plants but these data should be intrepreted cautiously as very few individuals on the roofs $(N=3)$ produced enough seeds to be used in our analysis. The lack of seed production in $B$. alba could be a possible consequence of this species requiring larger pollinators which have been found to be less abundant on green roofs compared to nearby ground level locations (Colla and Willis 2009, Ksiazek et al. 2012, Tonietto et al. 2011). However, providing supplemental pollen did not increase seed set compared to individuals pollinated naturally (Ksiazek et al. 2012) indicating that lack of pollinators may not be the only problem.

Seed mass tends to correlate positively with seedling success, particularly during the early germination stage (de Jong and Klinkhamer 2005), a trend observed in our experiment. There, both seed weight and seed set were correlated with germination success, whereby green roof populations having more, heavier seeds also had higher viability than populations on the ground (Ksiazek et al. 2012). In contrast, greater seed set is not necessarily expected to correlate with increased viability because of the common tradeoff between seed number and seed weight (de Jong and Klinkhamer 2005). However, under harsh environmental conditions such as drought some plants will produce larger, heavier seeds to increase the likelihood of seedling survival (Moles and Westoby 2004, Westoby et al. 1996) and a growing body of literature suggests that plant populations in stressed environments can experience increased fitness. Though the populations in our study were all within a 20-mile corridor and did not vary greatly in the amount of precipitation received, the hotter, windier and drier conditions that are typically experienced on green roofs compared to adjacent ground level habitat (Susca et al. 2011, Takahiro et al. 2010) can inflict additional stress on green roofs forbs (Carter and Butler 2008, Getter and Rowe 2006, Monterusso et al. 2005) and therefore affect seed production in green roof individuals. Soil profiles as well as available nutrients may also vary between green roofs and ground-level sites; factors which were not measured in our investigations but would benefit from further research to assess effects on seed number, size, viability, and subsequent germination and growth.

Genetic effects (genotype) could also account for differences in seed mass and germination. Many green roof installation companies choose seeds from robust lines that are easily propagated (Snodgrass and Snodgrass 2006). If the seed sources for green roof plants used in this study were chosen in this manner, this could contribute to the high quality of seeds collected during this investigation. As the seed source is not known for either of our site types, this variable could not easily be discounted. Additionally, genes which regulate germination may not directly control growth and development and it is important to point out that germination, per se, is not a direct measure of a seed's ability to develop into a healthy individual and reach reproductive maturity. 
Developing a deeper understanding of the ecological processes occurring on green roofs is crucial at a time when these novel habitats are becoming increasingly prevalent and native habitats are more fragmented throughout the world. Not only can native forbs be included in species mixes that provide environmental benefits on green roofs (Lundholm and MacIvor 2010) but they may also contribute to biodiversity conservation efforts such as providing habitat for a wide variety of, birds, spiders, molluscs and insects. While native plant conservation may not have been the original intention of green roof technology, the opportunity exists to design green roofs with such goals in mind which can make important contributions to biodiversity conservation, including specific plant and animal groups currently known to be threatened or endangered due to loss of habitat (Baumann 2006, Brenneisen 2006, Brenneisen and Hänggi 2006, Kadas 2006). The ability of a variety of native forb species to reproduce on green roofs is encouraging and suggests that using such species in these engineered habitats may be a successful management tool.

\section{Acknowledgements}

This research was funded in part by a grant from the deparment of Plant Biology and Conservation at Northwestern University and the Chicago Botanic Garden. We would like to thank the Chicago Botanic Garden, Chicago City Hall, Peggy Notebaert Nature Museum, Chicago Center for Green Technology, and Waters Elemetary School for allowing data collection at their sites, Daniel Larkin for assistance with experimental design, Chicago Botanic Garden volunteers for help with preparing and plating seeds, an anonymous peer reviewer for helpful comments in the original preparation of this document for the 2011 CitiesAlive conference proceedings and three anaonymous reviewers for comments on the current manuscript. 


\section{Literature Cited}

Baumann, N. "Ground-nesting birds on green roofs in Switzerland: Preliminary observations." Urban Habitats 4 (2006): 37-50.

Brenneisen, S. "Space for urban wildlife: Designing green roofs as habitats in Switzerland." Urban Habitats 4 (2006): 27-36.

Brenneisen, S. and A. Hänggi. "Begrünte Dächer - ökofaunistisch Charakterisierung eines neues Habitattyps in Siedlungsgebieten anhand eines Vergleichs der Spinnenfauna von Dachbegrünengen mit naturschutzrelevanten Bahnarealen in Basel (Schweiz)" [Green roofs - ecological faunal characterization of a new type of habitat in urban areas based on a comparison of the spider fauna of green roofs with conservation-related railway areas in Basel (Switzerland)], Mitteilungen der Naturforschenden Gesellschaften beider Basel 9 (2006): 99-122.

Carter, T. and C. Butler. "Ecological impacts of replacing traditional roofs with green roofs in two urban areas." Cities and the Environment 1.2 (2008): article 9.

Colla, S.R. and E. Willis. "Can green roofs provide habitat for urban bees (Hymenoptera: Apidae)?." Cities and the Environment 2.1 (2009): article 4.

Craine, J.M., D.A. Wedin, F.S. Chapin III and P.B. Reich. "Relationship between the structure of root systems and resource use for 11 North American grassland plants." Plant Ecology 165 (2003): 85-100.

Davis, J.D. and S.D. Hendrix. "Butterfly, bee and forb community composition and cross-taxon incongruence in tallgrass prairie fragments." Journal of Insect Conservation 12 (2008): 69-79.

de Jong, T.J. and P.G.L. Klinkhamer. Evolutionary Ecology of Plant Reproductive Strategies. Cambridge: Cambridge University Press, 2005.

Dunnett, N., A. Nagase, R. Booth and P. Grime. "Influence of vegetation composition on runoff in two simulated green roof experiments." Urban Ecosystems 11 (2008): 385-398.

Fernandez-Canero, R. and P. Gonzalez-Redondo. "Green roofs as a habitat for birds: A review." Journal of Animal and Veterinary Advances 9.15 (2010): 2041-2052.

Francis, R.A. and J. Lorimer. "Urban reconciliation ecology: The potential of living roofs and walls." Journal of Environmental Management 92 (2011): 1429-1437.

Getter, K.L. and D.B. Rowe. "The role of extensive green roofs in sustainable development." HortScience, 41.5 (2006): 1276-1285.

Hilty, John. "Illinois Wildflowers.” Copyright 2002-2012. http://www.illinoiswildflowers.info/index.htm.

Kadas, G. "Rare invertebrates colonizing green roofs in London." Urban Habitats 4.1 (2006): 66-73.

Ksiazek, K., J. Fant and K. Skogen. "An assessment of pollen limitation on Chicago green roofs." Landscape and Urban Planning 107 (2012): 401-408. 
Lundholm, J., and J.S. MacIvor. "Plant species and functional group combinations affect green roof ecosystem functions." PLOS ONE 5.3 (2010): 1-11.

MacIvor, J.S. and J. Lundholm. "Insect species composition and diversity on intensive green roofs and adjacent level-ground habitats." Urban Ecosystems 14.2 (2011): 225-241.

MacIvor, J.S. and J. Lundholm. "Performance evaluation of native plants suited to extensive green roof conditions in a maritime climate." Ecological Engineering 37 (2011): 407417.

Moles, A.T. and M. Westoby. "Seedling survival and seed size: a synthesis of the literature." Journal of Ecology 92.3 (2004): 372-383.

Monterusso, M.A., D.B. Rowe and C.L. Rugh. "Establishment and persistence of Sedum spp. and native taxa for green roof applications." HortScience 40.2 (2005): 391-396.

Oberndorfer, E.J., J. Lundholm, B. Bass, R.R. Coffman, H. Doshi, N. Dunnett, S. Gaffin, M. Köhler, K.K.Y. Liu and D.B. Rowe. "Green roofs as urban ecosystems: Ecological structures, functions, and services.” BioScience 57.10 (2007): 823-833.

R Development Core Team. "R: a language and environment for statistical computing." Vienna, Austria, R Foundation for Statistical Computing (2009).

Rosenzweig, M.L. "Reconciliation ecology and the future of species diversity." Oryx, 37.2 (2003): 194-205.

Rowe, D.B. "Green Roofs as a means of pollution abatement." Environmental Pollution 159 (2011): 2100-2110.

Snodgrass, E.C. and L.L. Snodgrass. Green Roof Plants. Portland: Timber Press, 2006.

Spala, A., H.S. Bagiorgas, M.N. Assimakopoulos, L. Kalavrouziotis, D. Matthopoulos and G. Mihalakakou. "On the green roof system. Selection, state of the art and energy potential investigation of a system installed in an office building in Athens, Greece." Renewable Energy 33 (2008): 173-177.

Sun, G., D.P. Coffin and W.K. Laurenroth. "Comparison of root distributions of species in North American grasslands using GIS.” Journal of Vegetation Science 8.4 (1997): 587-596.

Susca, T.R., S.R. Gaffin and G.R. Dell'Osso. "Positive effects of vegetation: Urban heat island and green roofs." Environmental Pollution 159 (2011): 2119-2126.

Takahiro, S., K. Michio, U. Yuichi and I. Noboru. "Evaluation of growth and green coverage of ten ornamental species for planting as urban rooftop greening." Journal of the Japanese Society for Horticultural Science 79 (2010): 69-76.

Tonietto, R., J. Fant, J. Ascher, K. Ellis and D. Larkin. "A comparison of bee communities of Chicago green roofs, parks and prairies." Landscape and Urban Planning 103 (2011): 102-108.

Westoby, M., M. Leishman and J. Lord. "Comparative ecology of seed size and dispersal." Philosophical Transactions: Biological Sciences 351.1345 (1996): 1309-1318. 